\title{
УДК:632.4.01/.08 https://doi.org/10.53040/gppb7.2021.92 \\ ПОРАЖЕННОСТЬ ЛИСТВЫ ДРЕВЕСНЫХ НАСАЖДЕНИЙ ГОРОДА КИШИНЕВА КОМПЛЕКСОМ ГНИЛЕЙ ЛЕТОМ 2021 ГОДА
}

\author{
Стратулат Татьяна, Щербакова Татьяна, Кручеан Штефан, Лунгу Андрей \\ Институт генетики, физиологии и защиты растений, Кишинэу, Республика Молдова \\ e-mail: tatiana.stratulat@igfpp.md
}

\begin{abstract}
To determine the complex of fungi that cause rot on the leaves and needles of tree species in the green spaces of Chisinau, foliage was collected in four sectors of the city. It was determined by microbiological methods that the complex of pathogens on the leaves differs little in different sectors. The main leaf rot fungi present on the affected leaves and needles are Alternaria sp., Aspergillus sp., Fusarium sp., Penicillium sp. For the treatment of the green spaces of Chisinau against diseases, it is advisable to carry out phytosanitary measures with biological products.
\end{abstract}

Key words: urban environment, green spaces, leaf phytopathogenic fungi.

По данным ВОЗ с 2010 г более 50\% населения земли живет в городской зоне, и эта цифра будет неуклонно расти. По прогнозам, к 2050 году до 70\% населения мира будет жить в больших и малых городах и муниципалитетах [1]. Одной из самых больших проблем муниципалитетов в настоящее время является решение экологических и климатических проблем. В условиях городской среды зеленые насаждения играют разнообразную роль: рекреационную, гигиеническую, эстетическую, оздоравливающую. Высадка зеленых насаждений позволяет снизить степень загрязнения окружающей среды транспортными и промышленными выбросами, уменьшить шумовое воздействие, улучшить микроклимат города и создать комфортные условия для жизни населения.

Здоровье жителей городов нельзя рассматривать как нечто независимое, автономное. Оно является результатом воздействия социальных и природных факторов и является одним из основных показателей устойчивого развития. В городских районах зеленые насаждения используются медицинскими центрами как форма естественной терапии для борьбы с болезнями, поскольку существует положительная связь между здоровьем и природой. Ряд исследований показали, что время, проведенное в естественной зеленой среде, снижает нервную активность, повышает иммунитет, стабилизирует частоту пульса, снижает холестерин, уровень кортизола в слюне (гормон стресса), а также систолическое и диастолическое артериальное давление [2].

Зеленые насаждения Кишинева - это особый элемент городской среды и область пересечения интересов различных социальных групп. По данным [3] в 2020 году площадь зеленых насаждений общего пользования (скверы, парки, лесопарки и зеленые насаждения вдоль дорог) в муниципии Кишинев составила 4192,1 га, а на одного городского жителя приходилось более 58 кв м зеленых зон отдыха. Фитосанитарное состояние и перспективы развития зеленых насаждений это целый комплекс сложных и очень важных научных и практических задач по сохранению здоровой, красивой и комфортной среды обитания в городе.

Важнейшим фактором негативного воздействия на фитосанитарное состояние зеленых насаждений г. Кишинева является комплекс болезней. В опубликованных отчетах оценки состояния древесных насаждений различных городов представлена информация о том, что в парковых насаждениях доминируют гнилевые болезни и различные инфекционные поражения листьев, тогда как в уличных посадках преобладают неинфекционные некрозы листьев и некрозно-раковые поражения стволов и ветвей [4]. В то же время в доступной литературе и базах данных не представлена информация о фитосанитарном состоянии зеленых насаждений г. Кишинева за последние 10 лет, об основных патогенах, вызывающих болезни таких широко произрастающих в муниципии деревьев как каштан, виды клена, виды липы, хвойные. 
Цель работы - провести оценку пораженности листвы отдельных представителей древесных лиственных и хвойных насаждений, произрастающих в различных районах г. Кишинева, в период вегетации 2021 года.

\section{Материалы и методы}

Фитосанитарные исследования. Для оценки фитосанитарного состояния древесных насаждений были отобраны пробы пораженных листьев наиболее типичных для г. Кишинева листопадных растений: липа, каштан, клен, вяз. Для оценки состояния хвойных пород отбирали пробы пораженной хвои, ели, сосны, туи, можжевельника, кипариса. Сбор листьев и хвои проводился в начале августа 2021 г. Пробы листьев и хвои отбирали из нижней части кроны, на уровне поднятой руки, стараясь задействовать ветки разных направлений (север, юг, запад, восток). Для анализа использовали только средневозрастные растения. У клена и каштана отбирали листья примерно одного, среднего для данного вида размера. С каштана и сосны дополнительно были отобраны шишки.

Микробиологические исследования. Выделение возбудителей гнилей из растительного материала проводили стандартным методом [5]. Пораженные листья и хвою поверхностно стерилизовали $2 \%$-м раствором перманганата калия в течение 1 минуты и промывали стерильной водой. Затем их разрезали стерильным скальпелем на кусочки и помещали в стерильные чашки Петри на сусло-агаровую среду с добавлением 80\%-й молочной кислоты, инкубировали в течение 1-7 суток при $25^{\circ} \mathrm{C}$. Выросшие грибы микроскопировали для определения родовой принадлежности.

Краткая характеристика мест отбора проб:

(1)Сектор Рышкань/Старая Почта; зеленые насаждения незначительные, в основном представлены видами клена, липы, каштана. Сбор листвы производили во дворах жилых домов, расположенных по улице Г. Мадан - ул. Язулуй.

(2)Городской Парк Рышкань/Старая почта. Значительные зеленые насаждения, вдоль магистрали представлены, в основном, представителями хвойных пород. Сбор хвои производили по линии ул. Каля Орхеюлуй.

(3)Сектор Ботаника; зеленые насаждения незначительные, в основном представлены видами клена, каштана. Сбор листвы по периметру аллей бульвар Траян - ул. Индепенденцей.

(4)Сектор Ботаника, ул. Пэдурий, 20, территория Института генетики, физиологии и защиты растений; значительные зеленые насаждения представлены видами клена, вяза, можжевельника, декоративными насаждениями туи, кустарниками. Сбор листвы и хвои.

\section{Результаты и обсуждения}

Городские древесные насаждения постоянно испытывают негативное влияние городской среды: повышенная загазованность воздуха, неблагоприятные свойства почвы, загрязненность ее веществами антропогенного происхождения, асфальтовое покрытие улиц и площадей, наличие подземных коммуникаций в зоне корневой системы, дополнительное освещение растений в ночное время. В результате снижается иммунитет, происходит заражение стволов и листвы вредными организмами, что приводит к более раннему физиологическому старению и даже гибели древостоя.

На протяжении последних 15 лет фитосанитарное состояние древесных насаждений (каштан, клен, липа, хвойные и т.д.) в городской местности представляет серьезную проблему не только в г. Кишиневе, но и в 46 городах по всей стране, а также и в соседних государствах. Наиболее широко в насаждениях Кишинева распространены болезни листьев. В период сезона вегетации 2021 г. отмечен высокий уровень распространения мучнистой росы на всех лиственных видах деревьев, которые хорошо визуально определялись уже с начала июля 2021 г. Для нас представляли интерес гнили на листьях и хвое, накопившиеся в течение нынешнего вегетационного периода.

В результате выделения грибов из пораженных листьев и хвои обозначился комплекс патогенов, практически одинаковый из всех мест сбора проб. В табл. 1 представлены общие данные взятых проб.

На листьях и хвое всех деревьев в преимуществе присутствовали грибы Alternaria sp. Они выделялись во всех пробах. Aspergillus niger отмечен на листве всех лиственных пород, в меньшей степени на хвойных - елях и соснах. Fusarium sp. на лиственных является вторичным патогеном, сильнее поражает хвою сосны и ели. Penicillium sp. и Aspergillus flavus встречаются в меньшинстве. На сосне и ели прослеживается комплекс гнилей, поражающий хвою: основание игл поражено фузариозом, кончики - грибами Alternaria, средняя часть - грибами Aspergillus (рис. 1, a). 
Таблица 1.Присутствие плесневых грибов на листве древесных насаждений города Кишинева (лето 2021 г.)

\begin{tabular}{|c|c|}
\hline $\begin{array}{c}\text { Название растений, } \\
\text { общепринятое/научное (место отбора) }\end{array}$ & Научные названия выделенных микромицетов \\
\hline $\begin{array}{l}\text { Каштан конский, } \\
\text { Aesculus hippocastanum L., (1), (3), (4) }\end{array}$ & $\begin{array}{l}\text { Alternaria sp., Fusarium sp., Aspergillus niger, Penicillium sp., } \\
\text { Trichoderma sp., Rhizopus sp. }\end{array}$ \\
\hline Липа, Tilia L. (1) & $\begin{array}{l}\text { Alternaria sp., Fusarium sp., Aspergillus niger, Penicillium sp., } \\
\text { Curvularia sp. }\end{array}$ \\
\hline Клен, Acer L. (1) & Alternaria sp., Aspergillus niger, Aspergillus flavus, Rhizopus sp. \\
\hline Вяз, Ulmus L. (3), (4) & $\begin{array}{l}\text { Alternaria sp., Fusarium sp., Aspergillus niger, Penicillium sp., } \\
\text { Trichoderma sp., Rhizopus }\end{array}$ \\
\hline Сосна обыкновенная Pinus sylvestris L.,(1) & $\begin{array}{l}\text { Alternaria sp., Fusarium sp., Aspergillus niger, Aspergillus flavus, } \\
\text { на шишках Alternaria sp. и Fusarium sp. }\end{array}$ \\
\hline Сосна обыкновенная Pinus sylvestris L.,(2) & Alternaria sp., Fusarium sp., Trichoderma sp. \\
\hline $\begin{array}{l}\text { Eль Picea A. Dietr. } \\
\text { (4) }\end{array}$ & $\begin{array}{l}\text { Alternaria sp., Fusarium sp., Aspergillus niger, Penicillium sp., } \\
\text { Trichoderma sp., Rhizopus sp. }\end{array}$ \\
\hline Можжевельник Juniperus L. (4) & Alternaria sp. \\
\hline $\begin{array}{l}\text { Можжевельник колючий Juniperus oxyce- } \\
\text { drus L. (3) }\end{array}$ & Alternaria sp., Rhizopus sp. \\
\hline Туя Thya L. (1) & Alternaria sp., Fusarium sp., Aspergillus niger, Rhizopus sp. \\
\hline
\end{tabular}

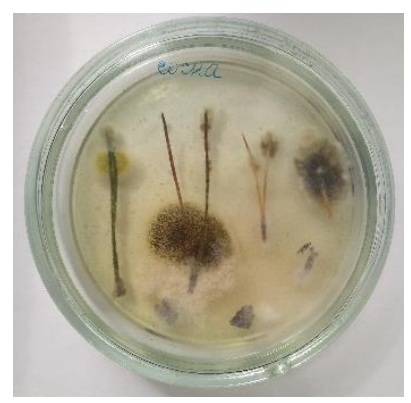

a) сосна

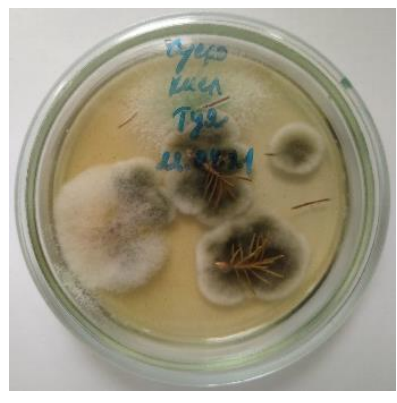

b) туя

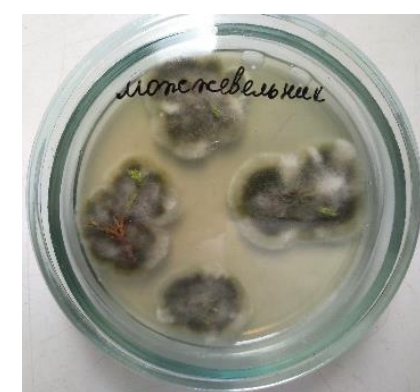

c) можжевельник

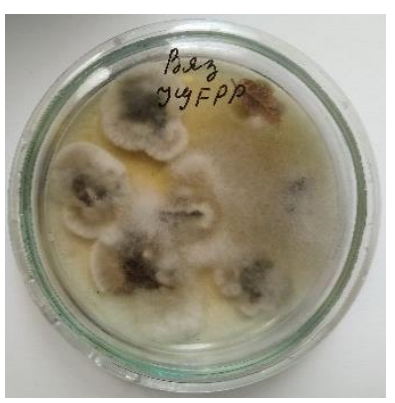

d) вяз

Рис. 1. Выделение фитопатогенов из пораженной листвы и хвои

Результаты выполненной оценки фитосанитарного состояния древесных насаждений г. Кишинева показали, что лиственные и хвойные деревья в городе поражены комплексом грибовфитопатогенов. Интенсивному развитию и сохранению в зимний период спор плесневых грибов способствовали благоприятные погодные условия, начиная с осени 2020 года. Сумма выпавших осадков за сентябрь-декабрь составила 246мм при норме 171мм (143\% от нормы). Не наблюдалось дефицита влаги и с начала 2021 года. Сумма осадков в январе-июле составила 463мм при норме 327 мм (141\% от нормы) [6].

Избыточное количество осадков способствовало развитию не только фитопатогенов, но и их антагонистов. Грибы рода Trichoderma являются гиперпаразитами многих фитопатогенов, они выделялись из листьев и хвои практически во всех пробах (табл. 1).

Плесневые грибы являются частой причиной аллергических заболеваний человека - аллергического ринита, конъюнктивита, атопического дерматита, бронхиальной астмы. В этом плане плесени оказывают более значимое воздействие на иммунную систему пациента, чем пыльца или другие бытовые аллергены. Основные виды плесневых грибов, чаще всего вызывающих развитие аллергий - Cladosporium, Alternaria, Penicillium и Aspergillus [7]. Как видно из результатов выполненной нами оценки, в пораженной болезнями кроне древесных насаждений г. Кишинева присутствуют три из четырех названных выше аллергена. Таким образом, улучшение фитосанитарного состояния деревьев в г. Кишиневе скажется позитивно на улучшении здоровья жителей города. 


\section{Выводы}

1. Проведенные исследования показали, что на листьях и хвое всех исследуемых деревьев преобладали грибы Alternaria sp.

2. Отмечено поражение хвои грибами Fusarium sp.

3. На всех лиственных породах, в меньшей степени на хвойных, встречаются Aspergillus sp. и Penicillium sp.

4. Для оздоровления парковых зон и зон озеленения города Кишинева рекомендуем проводить фитосанитарные мероприятия биологическими препаратами.

Работа выполнена при финансовой поддержке проекта Государственной программы № 20.80009.7007.16 ,Sinergismul dintre factorii naturali şi mijloacele microbiologice, ecologic inofensive, de reglare a densităţii populaţiilor de organisme dăunătoare pentru protecţia culturilor agricole în agricultura convențională şi ecologică” Республики Молдова.

1. Бюллетень ВО3. Выпуск 88, номер 4, апрель 2010 г.

\section{Литература}

2. MUHAMMAD, MUMTAZ KHAN, MUHAMMAD, TAHIR AKRAM, RHONDA, JANKE, RASHAD, WASEEM KHAN QADRI, ABDULLAH, MOHAMMED AL-SADI and AITAZAZ, A. FAROOQUE. Urban Horticulture for Food Secure Cities through and beyond COVID-19. Sustainability 2020, 12(22), 9592; https://doi.org/10.3390/su12229592

3. Structura, destinația și suprafața spațiilor verzi. Primăria municipiului Chișinău. https: //www.chisinau.md/public/files/Structura_destinatia_si_suprafata_spatiilor_verzi.pdf.

4. Доклад «О состоянии окружающей среды в городе Москва в 2016 году» / Под ред. А.О.Кульбачевского. - М.: ДПиООС; НИиПИ ИГСП, 2017. - 363 с.

5. БЁХТЕР, И. и др. Методы определения болезней и вредителей сельскохозяйствен-ных растений. / Пер. с нем. К.В. Попковой, В.А. Шмыгли. М.: Агропромиздат, 1987, 224 с.

6. Pogoda i klimat. http://www.pogodaiklimat.ru/archive.php. (дата обращения 15.08.2021).

7. ХРИСТОВА, Д., КАНДОВА, Я., НИКОЛОВ, Г., ПЕТРУНОВ, Б. Сенсибилизация к аллергенам плесневых грибов у пациентов с респираторной аллергией. Оптимизация диагностического процесса. // Журнал микробиологии, эпидемиологии и иммунобиологии. 2020, 97(2), с. 119-124. 